\title{
Improving Interaction Between Public Authorities and Business Structures in the Region
}

\author{
Vladislav Anichin \\ Department of Economics \\ Belgorod State Agricultural University named after V. Gorin \\ Belgorod, Russia \\ vladislavanichin@rambler.ru \\ Aleksandr Zhelyabovskiy \\ Department of Economics \\ Belgorod State Agricultural University named after V. Gorin \\ Belgorod, Russia \\ alex.zhelyabovskiy@gmail.com
}

\author{
Natalia Yakovenko \\ Department of Economics \\ Belgorod State Agricultural University named after V. Gorin \\ Belgorod, Russia \\ nata.jackovencko2010@yandex.ru \\ Galina Khudobina \\ Department of Economics \\ Belgorod State Agricultural University named after V. Gorin \\ Belgorod, Russia \\ galja4561@mail.ru
}

\begin{abstract}
The state and development of regions is largely determined by the interaction of public authorities and business structures. However, the issue of measuring the effectiveness of interaction remains open. We believe that the successful solution of socio-ecological and economic problems depends on the fullness of regional budgets, and budget self-sufficiency of regions is a function of interaction between government and business. Therefore, the indicator of budget self-sufficiency can be used as a quantitative criterion for the sustainable development of regions. The article analyzes the possibility of improving the interaction between government and business, based on this criterion. In parallel with the implementation of national projects, it is proposed to implement regional quasiprojects in the subjects of the Federation, which involve the coordination of work on various national projects and a new level of interaction between government and business. The article presents a three-factor regression model of the impact on the level of financial self-sufficiency of 81 subjects of the Russian Federation in 2017. The distribution of part of the variation between the factors of the regression model and the linear trend of the ratio of the number of employed and the population of the regions for 2013-2017 are also presented.
\end{abstract}

Keywords-region, sustainable development, budget selfsufficiency, interaction between government and business, improvement of interaction.

\section{INTRODUCTION}

The main features of the modern spatial development of the Russian Federation are, first, the combination of public administration and private entrepreneurship; secondly, the significant role of regions acting as quasi-corporations. Due to this, the state of the country's socio-ecological and economic system depends on the interaction of public authorities and business structures, the content and effectiveness of which is convenient to study in the context of the regions of the Russian Federation.
The role of business structures in this interaction is determined by the following: 1) the share of private enterprises in the total number of commercial organizations in modern Russia is more than $80 \%$; 2) the turnover of private enterprises also occupies a predominant share - up to $90 \%$ in certain regions; 3 ) the activity of business structures ensures employment of the population and revenues to the budgets of all levels. Therefore, the establishment of effective interaction between public authorities and regional business structures is of great importance for all regions.

\section{LITERATURE REVIEW}

The possibility of improving the interaction of public authorities and regional business structures is assessed by us based on the need to ensure sustainable development. According to V.S. Tsitlenok, the term "sustainability" should be considered in two aspects: 1) in a broad sense - as a concept for the development of a modern economy, implying expanded reproduction not only for business, but, first of all, in the environmental sphere; 2 ) in the narrow sense - as a dynamic equilibrium of the economy [1].

J.A. Mingaleva, K.A. Uzhegov associate the sustainable development of the region with the stability and integrity of the territory, maintaining a balance of socio-ecological and economic indicators. The economic aspect of sustainable development is expressed in the presence of a favorable market infrastructure, the formation of investment potential, the filling of the regional budget, the improvement of technology and organization of production, the maintenance of entrepreneurial activity [2].

A.V. Loktev and V.I. Menshchikova, analyzing the content of the concept of "sustainable development", distinguish two types of sustainability in relation to the regional economy: 1) the property of the system to return to 
the initial state of equilibrium; 2) the property of the system to move to a new equilibrium state. Stability of the first kind is a static equilibrium caused by the statics of phenomena and their insignificant volatility. Stability of the second kind is a dynamic equilibrium that occurs as a result of regular interactions of elements of complex socio-economic systems [3]. Sustainable development of the region as a process is characterized by an improvement in the quality of human life in all areas, including the state of the environment [4]. Sustainable development implies not only meeting the vital needs of people living today, but also greater opportunities to meet future needs [5].

The question inevitably arises as to what quantitative criterion should be used to assess the sustainability of the regional socio-ecological-economic system. We believe that in the context of improving the interaction between public authorities and business structures in the region, the most appropriate criterion is the indicator of the region's budgetary self-sufficiency.

Yu.V. Dubrovskaya and R.V. Gubaidullin are considered a generally accepted fact that the economic basis for the development of both countries and individual territories are budget revenues, which, as a rule, include tax and non-tax revenues, as well as attracted sources [6]. The ability of the region to independently finance its expenditure obligations significantly affects the level of economic development of the subject. The level of provision of budgetary services to the population, the quality of implementation of regional socioeconomic programs, and the general welfare of the population of the territory depend on the budgetary possibilities of the region [7].

Currently, in the Russian Federation, the revenues of the regional budget are mainly formed by deductions from federal taxes, such as personal income tax and corporate income tax. Of the regional taxes, the largest amount of revenues comes from the tax on the property of organizations [8]. The budgetary self-sufficiency of the region directly depends on the volume and content of the economic activity of regional business structures. The main manifestations of this activity are: the receipt of income by entrepreneurs and hired workers, the creation or acquisition of property objects. These manifestations serve a variety of interests, including personal, group, regional and national [9].

The budgetary self-sufficiency of a region means a situation in which regional business structures carry out their activities in such a way that the size of the taxable base of the region makes it possible to fill the majority of the regional budget. At present, in the structure of budgetary revenues of the subjects of the federation, most regions are characterized by a predominance of revenues from personal income tax. Only in some regions, for example, in 2017 in Belgorod, Leningrad, Tyumen, Irkutsk, Kemerovo, Sakhalin regions, the Republic of Kalmykia, the Republic of Tatarstan, Krasnoyarsk Territory, income tax revenues are higher than from personal income tax. This fact should not be interpreted as evidence of the lesser importance of profits for regional budgets compared to the income of individuals. Rather, it serves as evidence of the insufficient profitability of commercial organizations in most regions, which ultimately negatively affects the replenishment of the budgets of the subjects of the federation. In turn, the low profitability is caused, among other factors, by mistakes in the goal-setting of economic entities, the state of which does not generally correspond to the current stage of the country's development.

\section{MAIN PART}

To assess the region's budgetary self-sufficiency, the following indicator was used

$$
B S S=100-S G R,
$$

where BSS is the budgetary self-sufficiency of the region, $\%$; SGR is the share of gratuitous receipts to the regional budget, $\%$.

A similar indicator is used in [10]. As noted by N.Y. Grekova, I.L. Dolozina and A.O. Pinchuk, regions in most Federal countries do not have full budget self-sufficiency [11]. Therefore, the BSS indicator calculated for the regions of the Central Federal district in our case was less than $100 \%$. In the initial composition of factors that presumably affect the budgetary self-sufficiency of the region, we included the following indicators: the ratio of the employed to the population in the region (X1); specific receipts (per capita) to regional budgets for income tax (X2); personal income tax (X3); property taxes (X4); receipts from excise taxes on excisable goods (products) produced in the territory of the Russian Federation, per one inhabitant of the region (X5); share of break-even organizations in the region (X6). The regression model was built on the basis of the bulk of the regions of the Russian Federation. Four regions with an anomalous ratio of factor values and response were excluded from the total array: the Republic of Sakha (Yakutia), Kamchatka Territory, Magadan Region, Chukotka Autonomous Okrug.

The Forward Stepwise and Backward Stepwise procedures were used to select variables using the Statistica package, as well as the final analytical manual method, the essence of which is to find a compromise between the above procedures. The final version of the model includes three variables (Table 1).

The linear regression model is:

$$
B S S=-56,510+1,679 X_{1}+2,362 X_{5}+0,596 X_{6} .
$$

As one of the directions of analysis of the obtained result, it is of interest to estimate the ratio of the contributions of variables to the response variation explained by the model. Judging by the table 1 , the coefficient of determination is 0.543 , which means that this model explains $54.3 \%$ of the interregional variation in the BSS indicator.

variation in a number of statistical textbooks is proposed to be carried out using the coefficients of a separate definition, calculated for each factor included in the regression model:

$$
d_{j}^{2}=\frac{a_{j}}{\sigma_{Y}^{2}}\left(\overline{X_{j} Y}-\bar{X}_{j} \cdot \bar{Y}\right)=r_{X_{j}} \cdot \beta_{j} .
$$


TABLE I. THE THREE-FACTOR REGRESSION MODEL OF THE INFLUENCE ON THE LEVEL OF FINANCIAL SELF-SUFFICIENCY OF 81 REGIONS OF THE RUSSIAN FEDERATION IN 2017

\begin{tabular}{|l|l|l|l|l|l|l|}
\hline Variables & Beta & B & Std. Err. & $\boldsymbol{t}(\mathbf{7 6})$ & $\boldsymbol{p}$-level \\
\hline $\mathrm{X}_{1}$ & The ratio of the employed to the population in the region, \% & 0.632 & 1.679 & 0.206 & 8.157 & 0,000 \\
\hline $\mathrm{X}_{5}$ & $\begin{array}{l}\text { Regional budget receipts from excise taxes per one resident } \\
\text { of the region, thousand rubles }\end{array}$ & 0.229 & 2.362 & 0.822 & 2.875 & 0,005 \\
\hline $\mathrm{X}_{6}$ & Share of break-even organizations in the region, \% & 0.197 & 0.596 & 0.239 & 2.496 & 0,015 \\
\hline Intercept & -56.510 & 18.117 & -3.119 & 0.003 \\
\hline
\end{tabular}

Separation of the contribution of factors to the response

The sum of the coefficients of a separate determination is equal to the coefficient of multiple determination:

$$
R^{2}=\sum d_{j}^{2}
$$

Table 2 shows the results of this analysis for the three-factor model. Judging by the available information, the largest contribution to the interregional variation of budgetary self-sufficiency explained by the constructed model is made by $X_{1}$ "The ratio of employed to population, \%", the smallest - $X_{6}$ "Share of break-even organizations in the region, \%".

TABLE II. DISTRIBUTION OF THE EXPLAINED PART OF THE RESPONSE VARIATION (BSS) BETWEEN THE FACTORS OF REGRESSION MODELS

\begin{tabular}{|l|l|l|l|l|l|}
\hline \multicolumn{2}{|c|}{ Variables } & $\begin{array}{c}\text { Pairwise correlation } \\
\text { coefficient }\end{array}$ & Beta coefficient & $\begin{array}{c}\text { Coefficient of a separate } \\
\text { determination }\end{array}$ & $\begin{array}{c}\text { In \% to the } \\
\text { total }\end{array}$ \\
\hline $\mathrm{X}_{1}$ & $\begin{array}{l}\text { The ratio of the employed to the population in } \\
\text { the region. \% }\end{array}$ & 0.657 & 0.632 & 0.415 & 76.4 \\
\hline $\mathrm{X}_{5}$ & $\begin{array}{l}\text { Regional budget receipts from excise taxes per } \\
\text { one resident of the region, thousand rubles }\end{array}$ & 0.343 & 0.229 & 0.078 & 14.4 \\
\hline $\mathrm{X}_{6}$ & $\begin{array}{l}\text { Share of break-even organizations in the region, } \\
\%\end{array}$ & 0.251 & 0.197 & 0.050 & 9.1 \\
\hline Total & & 0.543 & 100 \\
\hline
\end{tabular}

The relatively small contribution of the factor "Share of break-even organizations in the region" to the formation of the response variation is partly explained by the fact that, firstly, the regions have different sectoral structures; second, the variation in the share of breakeven organizations by type of economic activity is several times higher than the variation across regions. The results obtained in the course of analysis of variance, in particular, indicate that in the Central Federal District this ratio is more than five.

So, at present, the determining factor of the budgetary self-sufficiency of the regions is the ratio of the number of employed and the population of the regions. This important analytical indicator, in turn, can be represented as the product of the employment of the region's labor force by the labor force share in the region's population

$$
\frac{\text { employed }}{\text { population }}=\frac{\text { employed }}{\text { work force }} \times \frac{\text { work force }}{\text { population }}
$$

The value of both factors depends on the actions of public authorities and regional business structures. If the employment of the population of the region is mainly influenced by the activity of regional business structures, then the size of the share of the labor force in the population is influenced by the current demographic policy. But in any case, the decisive factor is the interaction of public authorities and regional business structures.

It should also be borne in mind that the above factors differ significantly in terms of time. It is possible to change the employment situation on a national scale and a separate federal subject within a few years, while a similar change in the proportion of the labor force in the population takes decades, especially if there is a differentiation of regions in terms of living standards.

Earlier, we established the fact of significant and increasing differentiation of the regions of the Central Federal District by the level of income of the population [12]. The differentiation of regions in terms of the level of income of the population gives rise to labor migration and, as a consequence, a decrease in the proportion of the labor force in the population of regions with a relatively low level of income.

In the context of regions, there are various trends in the change in the proportion of employed and labor 
force, which made it possible to carry out a typical grouping (Table 3).

TABLE III. LINEAR TREND IN THE RATIO OF THE EMPLOYED AND THE POPULATION OF THE REGIONS AND THE FACTORS INFLUENCING IT (FOR 20132017)

\begin{tabular}{|c|c|c|c|c|}
\hline $\begin{array}{l}\text { Region } \\
\text { groups }\end{array}$ & $\begin{array}{l}\text { Regions of the Central Federal } \\
\text { District }\end{array}$ & $\begin{array}{c}\text { Employed to population, } \\
\% \\
\end{array}$ & $\begin{array}{c}\text { Employed to labor force, } \\
\% \\
\end{array}$ & $\begin{array}{l}\text { Labor force to } \\
\text { population, \% }\end{array}$ \\
\hline \multirow{3}{*}{$8=$} & Belgorod region & 1.0 & 1.7 & 0.1 \\
\hline & Voronezh region & 0.5 & 0.7 & 0.2 \\
\hline & Moscow city & 4.4 & 7.4 & 0.1 \\
\hline \multirow{6}{*}{ II } & Bryansk region & 0.1 & 0.4 & -0.2 \\
\hline & Kaluga region & 0.4 & 1.2 & -0.3 \\
\hline & Lipetsk region & 0.7 & 1.6 & -0.2 \\
\hline & Moscow region & 1.2 & 2.3 & -0.1 \\
\hline & Ryazan region & 0.5 & 1.3 & -0.2 \\
\hline & Tver region & 1.1 & 2.4 & -0.3 \\
\hline \multirow{5}{*}{ III } & Ivanovo region & -0.7 & -1.8 & 0.2 \\
\hline & Kostroma region & -0.3 & 0.1 & -0.5 \\
\hline & Vladimir region & -0.9 & -1.0 & -0.4 \\
\hline & Tambov region & -0.1 & -0.3 & 0.1 \\
\hline & Tula region & -0.4 & -0.9 & 0.0 \\
\hline \multirow{4}{*}{ IV } & Kursk region & -1.3 & -2.4 & -0.1 \\
\hline & Oryol region & -2.3 & -4.3 & -0.1 \\
\hline & Smolensk region & -1.0 & -1.6 & -0.2 \\
\hline & Yaroslavl region & -0.2 & 0.1 & -0.3 \\
\hline
\end{tabular}

Group I is represented by regions with positive dynamics in all three indicators. Group II - regions with positive dynamics of the main indicator (the ratio of the employed to the population) and any other. Group III regions with negative dynamics of the main indicator and positive dynamics of one of the factors. Group IV regions with negative dynamics in all indicators.

The results of a typical grouping were used for the development and comparative assessment of scenarios for interaction between public authorities and regional business structures.

The first scenario (pre-project) assumes the preservation of the trends identified above, in which the socio-economic development of the regions will occur with the interaction of public authorities and regional business structures, which have developed by 2018 .

In general, there are two main types of interaction between public authorities and regional business structures: 1) contactless interaction; 2) contact interaction.

As we established earlier, "the mechanism of contactless interaction includes such tools of influence as goal-setting, disclosure of the results of activities and intentions. A distinctive feature of contact interaction is communication, the intermediate result of which is a verbal agreement or a written agreement, and the end result is actions agreed by the parties. Most of the types of contact forms are regulated by regulatory legal acts. The mechanism of contact interaction includes tools that allow you to quickly influence the actions of the parties.
These include: negotiations, warnings, additional proposals. Contactless interaction is characterized by the absence of any agreements between the parties, each of which acts on the basis of its own interests, taking or not taking into account the actions of the other party and the circumstances arising from this" [13].

Many researchers see the prospects for interaction between government and business structures in the implementation of the project approach, in the implementation of a set of mutually beneficial projects [14]. It is equally important to provide conditions for interaction in the course of the current activities of public authorities and business entities. In this context, it is of fundamental importance to coordinate the interests of power structures and business, which is implemented by such a management function as goal-setting [15].

On May 7, 2018, the President of Russia signed a decree "On national goals and strategic objectives for the development of the Russian Federation for the period up to 2024", establishing and approving national projects in Russia. New national projects on a federal scale cover three areas: Human Capital, Comfortable Environment for Life and Economic Growth. A number of national projects determine the current and future nature of interaction between public authorities and regional business structures.

In this regard, the second scenario (the project scenario) assumes the socio-economic development of regions with the interaction of public authorities and regional business structures in the context of the implementation of national projects. 
The analysis performed shows that the actions envisaged by the national projects are insufficiently coordinated, both within the boundaries of individual projects and in the interproject space. Therefore, it is also advisable to consider the development of regions in the interaction of public authorities and regional business structures in the context of the implementation of coordinated national projects (scenario of coordinated projects).

The predicted group values of the budgetary selfsufficiency of the Central Federal District regions under the pre-project scenario are presented in Table 4.

\section{TABLE IV. FORECAST OF THE AVERAGE BUDGETARY SELF-SUFFICIENCY BY GROUPS OF REGIONS OF THE CENTRAL FEDERAL DISTRICT (THE PRE-PROJECT SCENARIO), \%}

\begin{tabular}{|c|c|c|c|c|c|c|}
\hline $\begin{array}{l}\text { Region } \\
\text { groups }\end{array}$ & Regions of the Central Federal District & 2020 & 2021 & 2022 & 2023 & 2024 \\
\hline \multirow[t]{3}{*}{$\mathrm{T}$} & Belgorod region & \multirow{3}{*}{88.20} & \multirow{3}{*}{89.21} & \multirow{3}{*}{90.18} & \multirow{3}{*}{91.12} & \multirow{3}{*}{92.02} \\
\hline & Voronezh region & & & & & \\
\hline & Moscow city & & & & & \\
\hline \multirow{6}{*}{ II } & Bryansk region & \multirow{6}{*}{81.30} & \multirow{6}{*}{82.60} & \multirow{6}{*}{83.84} & \multirow{6}{*}{85.04} & \multirow{6}{*}{86.19} \\
\hline & Kaluga region & & & & & \\
\hline & Lipetsk region & & & & & \\
\hline & Moscow region & & & & & \\
\hline & Ryazan region & & & & & \\
\hline & Tver region & & & & & \\
\hline \multirow{5}{*}{ III } & Ivanovo region & \multirow{5}{*}{66.30} & \multirow{5}{*}{65.06} & \multirow{5}{*}{63.80} & \multirow{5}{*}{62.52} & \multirow{5}{*}{61.21} \\
\hline & Kostroma region & & & & & \\
\hline & Vladimir region & & & & & \\
\hline & Tambov region & & & & & \\
\hline & Tula region & & & & & \\
\hline \multirow{4}{*}{ IV } & Kursk region & \multirow{4}{*}{67.37} & \multirow{4}{*}{65.40} & \multirow{4}{*}{63.41} & \multirow{4}{*}{61.40} & \multirow{4}{*}{59.37} \\
\hline & Oryol region & & & & & \\
\hline & Smolensk region & & & & & \\
\hline & Yaroslavl region & & & & & \\
\hline
\end{tabular}

During the elaboration of the project scenario, the following were taken into account: 1) the expected increase in employment in the field of education in connection with the creation of new places in general educational organizations; 2) the expected increase in employment in small and medium-sized enterprises; 3 ) the expected decrease in the number of employed women due to the increase in the number of women who took three-year parental leave; 4) the expected increase in the average annual population from the increase in the number of births.

The scenario calculations performed cover the medium term, while, for example, the effect of the national project "Demography" will come no earlier than 20 years later, when the current stimulation of the birth rate will lead to an increase in the working-age population.

Nevertheless, in the context of our research, the indicator "Number of births" is important because its expected dynamics in connection with the planned operations of the national project will affect the number of employed in the medium term.

The scenario in which, in parallel with the implementation of national projects in the constituent entities of the federation, regional quasi-projects are being implemented, was called in our study the "scenario of coordinated projects". The essence of regional quasi-projects is characterized by the following features:
- cross-financing, expressed in the use of funds allocated for the implementation of national projects, and funds of regional business structures;

- interdepartmental management, assuming that the final decision on the operations of national projects is taken by the departments in charge of these projects;

- a matrix organizational structure, including quasisubdivisions of a quasi-project: departments and regions involved in its implementation;

- orientation of the owners of business structures towards a balanced goal-setting that meets the interests of sustainable development of the region, should be one of the directions of the economic policy of each region;

- actions of the initiative group lobbying for the coordination of operations of national projects to achieve the goals of the quasi-project in the interests of the stakeholders of the region (macroregion);

- availability of a plan for the effective spatial distribution of the consolidated resources of national projects within the boundaries of the macro-region and regions.

As a result, the average budgetary self-sufficiency of the regions under the scenario of coordinated projects is noticeably higher than under other scenarios. 
Scenario calculations were performed using a three-factor regression model of the influence of a complex of factors on the level of financial selfsufficiency of the regions, the parameters of which are presented in Table. 1, and the expected dynamics of the factors included in this model.

Comparison of the expected values of the budgetary self-sufficiency of the regions under various scenarios shows that the management of interaction between the public authorities and regional business structures based on project coordination will provide a greater effect than the effect of the implementation of separate national projects (Table 5).

Improving the interaction of public authorities and regional business structures is especially important in the context of budget deficit [16]. On the other hand, as our research has shown, effective interaction can increase the budgetary self-sufficiency of the region.

TABLE V. INCREASE IN AVERAGE BUDGETARY SELF-SUFFICIENCY BY GROUPS OF REGIONS OF THE CENTRAL FEDERAL DISTRICT IN 2024 IN THE IMPLEMENTATION OF THE SCENARIO OF COORDINATED

PROJECTS IN COMPARISON WITH THE PRE-PROJECT SCENARIO, \%

\begin{tabular}{|c|c|c|c|c|}
\hline \multirow{2}{*}{$\begin{array}{l}\text { Region } \\
\text { groups }\end{array}$} & \multirow{2}{*}{$\begin{array}{l}\text { Regions of the } \\
\text { Central Federal } \\
\text { District }\end{array}$} & \multirow{2}{*}{$\begin{array}{l}\text { Increase, } \\
\text { total }\end{array}$} & \multicolumn{2}{|c|}{$\begin{array}{l}\text { including through } \\
\text { the } \\
\text { implementation of: }\end{array}$} \\
\hline & & & $\begin{array}{l}\text { national } \\
\text { projects }\end{array}$ & $\begin{array}{l}\text { regional } \\
\text { quasi- } \\
\text { projects }\end{array}$ \\
\hline \multirow{3}{*}{ I } & Belgorod region & \multirow{3}{*}{2.13} & \multirow{3}{*}{0.13} & \multirow{3}{*}{2.00} \\
\hline & Voronezh region & & & \\
\hline & Moscow city & & & \\
\hline \multirow{6}{*}{ II } & Bryansk region & \multirow{6}{*}{2.15} & \multirow{6}{*}{0.19} & \multirow{6}{*}{1.96} \\
\hline & Kaluga region & & & \\
\hline & Lipetsk region & & & \\
\hline & Moscow region & & & \\
\hline & Ryazan region & & & \\
\hline & Tver region & & & \\
\hline \multirow{5}{*}{ III } & Ivanovo region & \multirow{5}{*}{1.87} & \multirow{5}{*}{0.16} & \multirow{5}{*}{1.71} \\
\hline & Kostroma region & & & \\
\hline & Vladimir region & & & \\
\hline & Tambov region & & & \\
\hline & Tula region & & & \\
\hline \multirow{4}{*}{ IV } & Kursk region & \multirow{4}{*}{2.09} & \multirow{4}{*}{0.13} & \multirow{4}{*}{1.96} \\
\hline & Oryol region & & & \\
\hline & Smolensk region & & & \\
\hline & Yaroslavl region & & & \\
\hline
\end{tabular}

\section{CONCLUSION}

The main guideline for improving the interaction of public authorities and business structures should be the sustainable development of the region. The ability of a region to expanded reproduction of its own socioecological and economic system is determined by budgetary self-sufficiency. In turn, budgetary selfsufficiency is determined by the content of interaction between government and business. A feature of the current stage of development of Russian regions is the implementation of large-scale national projects. Managing the interaction of public authorities and regional business structures on the basis of coordinating the implementation of national projects within the boundaries of a regional quasi-project is a key factor in ensuring sustainable development of regions.

Changes in the state of interaction between public authorities and regional business structures should be assessed by the dynamics of the ratio of employed to the population of the region and the dynamics of the level of budget self-sufficiency in the region.

Of interest are further studies of the application of the indicator of the region's budgetary self-sufficiency as a criterion for the sustainable development of the region. In particular, it seems promising to determine the optimal level of budgetary self-sufficiency of a particular region in the network of interacting regions of Russia. It is also relevant to generalize the regional experience of interaction between public authorities and business.

\section{REFERENCES}

[1] V.S. Tsitlenok, I.V. Roshchina, N.A. Artyukhova, Sustainable development of the economy of the Russian Federation: a factor of structural and multi-level diversity Federacii, Tomsk, 2019.

[2] Zh.A. Mingaleva, K.A. Uzhegova, "Features of partnership implementation in the concept of regional sustainable development: hierarchical interaction", Bulletin of PNRPU. Social and economic Sciences, 1, 2016, pp. 152-160.

[3] A.V. Loktev, V.I. Menshchikova, "Sustainable development of the region's economy: basic conditions and mechanism of support", Socio-economic phenomena and processes, 10, 44, 2012, pp. 115122.

[4] R. Jovovic, M. Draskovic, M. Delibasic, M. Jovovic, "The concept of sustainable regional development - institutional aspects, policies and prospects", Journal of International Studies, 10 (1), 2017, pp. 255-266, doi:10.14254/2071-8330.2017/10- 1/18.

[5] N. Mammadov, Sustainable socio-economic development of regions is the basis of national economy security. Economic and Social Development: Book of Proceedings, 3, 2020, pp. 384-388.

[6] Yu. V. Dubrovskaya, R.V. Gubaidullina. "Public-private partnership as a factor of balanced regional development". Bulletin of Perm University. Series: Economics, 1 (24) (2015), pp. 35-45.

[7] A.A. Aivazov, "Assessment and directions of development of the budget potential of the subject of the Russian Federation", Audit and financial analysis, 6, 2009, pp. 14-15.

[8] A.A. Kuklin, K.S. Nalunga, "Methodological features of the assessment of regional budgets", Regional economy, 2, 2018, pp. 395-407.

[9] V.L. Anichin, A.Yu. Zhelyabovsky, Improving the interaction of public authorities and business structures in regional economic management, Belgorod, 2019.

[10] V. Grebennikov, B. Yerznkyan, R. Magomedov, "Governmental Programming of Regional Budgetary SelfSufficiency", Montenegrin Journal of Economics, 16 (2), 2020, pp. 219-233.

[11] N.Y. Rekova, I.L. Dolozina, A.O. Pinchuk, "Budgetary revenue breakdown at regional level of public administration in the federal countries". Scientific bulletin of Polissia, 2, 2018, pp. 34-42. [12] V.L. Anichin, A.Yu. Zhelyabovsky, "Measurement of regional differentiation of monetary incomes of the population", Scientific Bulletin of the Belgorod state University. Series: Economics. Informatics, 9, 2016, pp. 5-9.

[13] V.L. Anichin, A.Yu. Zhelyabovsky, "Forms and mechanisms of interaction between public authorities and regional business structures", Innovations in Agricultural Complex: problems and perspective, 2019, pp. 93-99. 
[14] Y.I. Mikhailov, A.S. Sokolitsyn, D.V. Ivanov, Project Financing in the Interaction of Regional and Municipal Authorities and Business Structures, 2018, IEEE International Conference "Quality Management, Transport and Information Security, Information Technologies" (IT\&QM\&IS), St. Petersburg, 2018, pp. 854-856, doi: 10.1109/ITMQIS.2018.8525076.

[15] A.Yu. Zhelyabovsky, "The role of goal setting in the mechanism of the management of sustainable regional development", Regional economy. South of Russia, 4, 2018, pp. 8085.

[16] T.V. Uskova, S.A. Kozhevnikov, "Management of the regional economy on the basis of partnership interaction between the authorities and business structures", Economic and Social Changes: Facts, Trends, Forecast, 6, 2014, pp. 34-46. 